\title{
Magnetic and spectral signatures of Cerrado soils in the state of Goiás, Brazil
}

\author{
Kathleen Lourenço Fernandes ${ }^{(1)}$, Adriana Aparecida Ribon ${ }^{(2)}$, José Marques Junior(1), \\ Angélica Santos Rabelo de Souza Bahia(1) and João Tavares Filho(3)
}

\begin{abstract}
(1)Universidade Estadual Paulista Júlio de Mesquita Filho, Faculdade de Ciências Agrárias e Veterinárias, Campus de Jaboticabal, Via de Acesso Prof. Paulo Donato Castellane, s/no, CEP 14884-900 Jaboticabal, SP, Brazil. E-mail: kathleen_agro@hotmail.com, marques@fcav.unesp.br, angelicasantosrabelo@yahoo.com.br (2)Universidade Estadual de Goiás, Campus Palmeiras de Goiás, Rua S-7, s/no, Setor Sul, CEP 76190-000 Palmeiras de Goiás, GO, Brazil. E-mail: adriana.ribon@ueg.br (3)Universidade Estadual de Londrina, Rodovia Celso Garcia Cid, Pr 445, Km 380, Caixa Postal 10.011, CEP 86057-970 Londrina, PR, Brazil. E-mail: tavares@uel.br
\end{abstract}

Abstract - The objective of this work was to estimate the iron oxide contents (hematite and goethite) and to characterize the color and the spectral and magnetic signatures of Cerrado soils in the state of Goiás, Brazil. Six Oxisols and one Inceptisol were studied. Spectral and magnetic signatures were determined by diffuse reflectance spectroscopy (DRS) and magnetic susceptibility, respectively. Then, the spectral curves and the second derivative calculations were used to determine hematite and goethite contents, as well as soil color after conversion into tristimulus values. Hematite and goethite contents were also obtained by x-ray diffractometry, and soil color was also defined in the field (Munsell color chart). The values for the isomorphic substitution of iron by aluminum and the degree of redness were also determined. DRS can be used to estimate hematite and goethite contents, as well as the color of Cerrado soils in the state of Goiás. The spectral signature can point out the main soil properties related to the contents of organic matter, iron oxides, kaolinite, and gibbsite. The magnetic signature, characteristic of soils rich in iron oxides (hematite and goethite), shows the predominance of pedogenic minerals.

Index terms: diffuse reflectance spectroscopy, goethite, hematite, magnetic susceptibility, Oxisols.

\section{Assinaturas magnéticas e espectrais de solos do Cerrado de Goiás}

Resumo - O objetivo deste trabalho foi estimar os teores de óxidos de ferro (hematita e goethita) e caracterizar a cor e as assinaturas espectrais e magnéticas de solos do Cerrado de Goiás. Foram estudados seis Latossolos e um Cambissolo. As assinaturas espectrais e magnéticas foram determinadas por espectroscopia de reflectância difusa (ERD) e suscetibilidade magnética, respectivamente. Posteriormente, as curvas espectrais e os cálculos de derivativos secundários foram utilizados para determinar os conteúdos de hematita e goethita, além da cor dos solos após conversão em valores tristimulus. Os teores de hematita e goethita também foram obtidos por difratometria de raios-X, e a cor dos solos também foi avaliada em campo (carta de Munsell). Também foram determinados os valores de substituição isomórfica do ferro por alumínio e o índice de avermelhamento dos solos. A ERD pode ser utilizada para estimar os conteúdos de hematita e goethita, bem como a cor dos solos do Cerrado de Goiás. A assinatura espectral é capaz de apontar as principais características dos solos relacionadas aos conteúdos de matéria orgânica, óxidos de ferro, caulinita e gibbsita. A assinatura magnética, característica de solos ricos em óxidos de ferro (hematita e goethita), mostra o predomínio de minerais pedogenéticos.

Termos para indexação: espectroscopia de reflectância difusa, goethita, hematita, suscetibilidade magnética, Latossolos.

\section{Introduction}

The soil is a complex system that requires proper management to avoid possible risks of degradation, ensuring food security and sustainable development. Understanding soils, considering all their attributes and processes of formation, is essential to monitor them
(Viscarra Rossel et al., 2016). However, laboratory analyses are generally costly and time-consuming, restricting the number of samples representative of a region (Viscarra Rossel, 2011; Bahia et al., 2015; Demattê et al., 2016). In this context, the use of spectral signature emerges as an alternative methodology for this task. 
Diffuse reflectance spectroscopy (DRS) and magnetic susceptibility (MS) are alternative techniques that can be used to estimate soil properties such as: iron oxides (Viscarra Rossel et al., 2010; Bahia et al., 2015); silicate minerals, including kaolinite, illite, and smectite (Viscarra Rossel, 2011; Mulder et al., 2013); chemical attributes and grain size (Marques Jr. et al., 2014; Demattê et al., 2016; Viscarra Rossel et al., 2016); phosphorus adsorption (Camargo et al., 2015; Peluco et al., 2015); and soil color (Aquino et al., 2016; Carmo et al., 2016).

Although these techniques have been adopted in several studies, there are few local researches on soils in the Cerrado in the state of Goiás, Brazil. Demattê et al. (2016) assessed models for the prediction of soil attributes that were generated using a spectral database from multiple locations. According to these authors, the more complete and broad a spectral library of soils is in a given region, the better will be the quality of the evaluation of the attributes, processes, and management of such soils.

The objective of this work was to estimate the iron oxide contents (hematite and goethite) and to characterize color and the spectral and magnetic signatures of soils in the Cerrado in the state of Goiás, Brazil.

\section{Materials and Methods}

The study was conducted in the Cerrado biome, in the municipality of Campestre de Goiás, in the south

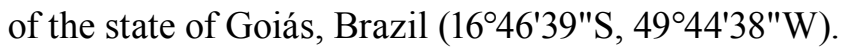
The climate type of the region, according to Köppen's classification, is tropical wet (Aw), with dry winters and rainy summers (Ribeiro \& Walter, 2008). The source material from the site is composed of metamorphic metagranites of the Jurubatuba formation from the Proterozoic age, as characterized by Fernandes et al. (2016).

For the experiment, seven soil profiles were selected, classified according to Santos et al. (2013): S1, Latossolo Amarelo distrocoeso típico (Xanthic Hapludox) (LAdx-1); S2, Cambissolo Háplico Tb eutrófico latossólico (Eutrochrept) (CXbe); S3, Latossolo Amarelo eutrófico típico (Xanthic Eutrudox) (LAe1); S4, Latossolo Vermelho eutrófico chernossólico (Rhodic Eutrudox) (LVe); S5, Latossolo Amarelo distrocoeso típico (Xanthic Hapludox) (LAdx-2); S6,
Latossolo Vermelho-Amarelo eutrófico típico (Typic Eutrudox) (LVAe-1); S7, Latossolo Amarelo eutrófico típico (Xanthic Eutrudox) (LAe-2). Table 1 shows the grain size and chemical characteristics of the evaluated soils.

Total iron oxide content - dithionite $\left(\mathrm{Fe}_{\mathrm{d}}\right)$ - was determined by extraction by sodium dithionite-citratebicarbonate, following the methodology of Mehra \& Jackson (1960), and the dosage of iron was measured by atomic absorption spectrophotometry. The content of iron oxide of low crystallinity $\left(\mathrm{Fe}_{\mathrm{o}}\right)$ was obtained by extraction by ammonium oxalate, according to Camargo et al. (1986).

For the mineralogical analysis, the clay fraction was separated only in the diagnostic horizons. The samples were subjected to mechanical agitation with $\mathrm{NaOH}$ $0.5 \mathrm{~mol} \mathrm{~L}^{-1}$ for $10 \mathrm{~min}$ for particle dispersion. After this treatment, the sand fraction was removed with a $0.05-\mathrm{mm}$ sieve. The silt fraction was separated by centrifugation at $1,600 \mathrm{rpm}$, and the running time for the procedure varied according to the temperature of the samples at the time of analysis. The clay suspension was flocculated with concentrated $\mathrm{HCl}$ and centrifuged at 2,000 rpm for $2 \mathrm{~min}$.

For the characterization of the minerals hematite $(\mathrm{Hm})$ and goethite $(\mathrm{Gt})$, the concentration of oxides was determined with $\mathrm{NaOH} 5 \mathrm{~mol} \mathrm{~L}^{-1}(1 \mathrm{~g}$ clay per $100 \mathrm{~mL}$ solution), according to the method of Norrish \& Taylor (1961) modified by Kämpf \& Schwertmann (1983). To maintain the minimum concentration of silicic acid in the solution of $\mathrm{NaOH} 5 \mathrm{~mol} \mathrm{~L}^{-1}, 10 \%$ by weight of ground silica gel was added, avoiding changes in aluminum replacement and goethite crystallinity (Kämpf \& Schwertmann, 1983). To prevent sodalite from hampering the reading of the diffractograms, the samples were washed with a solution of $\mathrm{HCl} 0.5 \mathrm{~mol} \mathrm{~L}^{-1}$ ( $1 \mathrm{~g}$ clay per $100 \mathrm{~mL}$ solution) and stirred for 4 hours. Deviations in the positions (d) of the reflections being studied were corrected by adding to the samples $10 \%$ by weight of sodium chloride, which was ground and sieved in a $0.10-\mathrm{mm}$ mesh before diffraction.

Subsequently, the minerals were characterized by X-ray diffraction (XRD) in a MiniFlex II unit (Rigaku Americas Corporation, Woodlands, TX, USA), using a copper cathode, with a nickel filter and $\mathrm{K} \alpha$ radiation $(20 \mathrm{~mA}, 30 \mathrm{Kv})$, and the dust method. Scanning speed was $1^{\circ} 2 \theta$ per minute with an amplitude of 23 to $49^{\circ} 2 \theta$ for the characterization of $\mathrm{Hm}$ and $\mathrm{Gt}$. 
To calculate the isomorphous replacement $\left(\mathrm{mol} \mathrm{mol}^{-1}\right)$ of iron by aluminum in Gt, the procedures suggested by Schulze \& Schwertmann (1984) were followed. To estimate Gt content, crystalline iron content was multiplied by the $\mathrm{Gt} /(\mathrm{Gt}+\mathrm{Hm})$ ratio and by 1.59 . For $\mathrm{Hm}$, crystalline iron content was multiplied by 1.43 , after subtracting from this value the amount of iron corresponding to Gt (Dick, 1986).

To obtain the DRS spectra, approximately $1 \mathrm{~g}$ airdry fine earth (ADFE) - from the diagnostic horizons - was ground (Barron \& Torrent, 1986; Torrent \& Barrón, 1993) in agate mortar until obtaining a constant color, and the content was placed in a sample holder with an inner cylinder (16 $\mathrm{mm}$ in diameter). The reflectance values were measured in a Lambda 950 UV/Vis/NIR spectrophotometer (Perkin Elemer do
Brasil, São Paulo, SP, Brazil) coupled with a $150-\mathrm{mm}$ integrating sphere. The spectra were recorded at every $0.5 \mathrm{~nm}$, with integration time of $2.43 \mathrm{~nm} \mathrm{~s}^{-1}$ over the range of 380 to $780 \mathrm{~nm}$ (visible region) and the NIR.

The contents of $\mathrm{Hm}$ and Gt were estimated by applying the second derivative of the Kubelka-Munk function (Kubelka \& Munk, 1931). The absorption bands typical of iron oxides were identified in the curves of the second derivative (Kosmas et al., 1984; Scheinost et al., 1998). For the identification of Gt and $\mathrm{Hm}$, the minimum ranges adopted were 415-425 and 530-545 $\mathrm{nm}$, respectively, and the maximum ranges were 440-450 and 575-590 nm (Bahia et al., 2014). The value of the amplitudes of the absorption bands of Gt and $\mathrm{Hm}$ were used to calculate the correlation with the estimated quantity of these minerals, according

Table 1. Grain size, chemical properties, and sulfuric acid content of the studied soils ${ }^{(1)}$.

\begin{tabular}{|c|c|c|c|c|c|c|c|c|c|c|c|c|}
\hline \multirow[t]{3}{*}{ Soil } & \multirow[t]{2}{*}{ Depth } & \multirow[t]{3}{*}{ Horizon } & \multirow{3}{*}{$\begin{array}{c}\mathrm{pH} \\
\mathrm{H}_{2} \mathrm{O}\end{array}$} & \multirow{3}{*}{$\begin{array}{c}\text { Base } \\
\text { saturation } \\
(\%) \\
\end{array}$} & \multirow[t]{3}{*}{ SOM } & \multicolumn{3}{|c|}{ Grain size } & \multirow[t]{3}{*}{$\mathrm{SiO}_{2}$} & \multirow[t]{3}{*}{$\mathrm{Al}_{2} \mathrm{O}_{3}$} & \multirow[t]{3}{*}{$\mathrm{Fe}_{2} \mathrm{O}_{3}$} & \multirow[t]{3}{*}{$\mathrm{Ki}$} \\
\hline & & & & & & Sand & Silt & Clay & & & & \\
\hline & $(\mathrm{m})$ & & & & & ----- & $---\cdot-\cdot$ & $\left(\mathrm{g} \mathrm{kg}^{-1}\right)$ & & & & \\
\hline \multirow{4}{*}{ S1 (LAdx-1) } & $0.00-0.28$ & $\mathrm{~A}$ & 5.30 & 27.00 & 2.40 & 186 & 127 & 687 & - & - & - & - \\
\hline & -0.63 & $\mathrm{~A} / \mathrm{B}$ & 5.00 & 26.00 & 1.50 & 166 & 107 & 727 & - & - & - & - \\
\hline & -1.21 & $\mathrm{Bw}_{1}$ & 5.50 & 15.00 & 6.00 & 146 & 167 & 687 & 100.00 & 135.00 & 70.25 & 1.30 \\
\hline & $-1.60+$ & $\mathrm{Bw}_{2}$ & 6.20 & 63.00 & 7.00 & 186 & 247 & 567 & - & - & - & - \\
\hline \multirow{4}{*}{ S2 (CXbe) } & $0.00-0.25$ & $\mathrm{~A}$ & 5.67 & 66.27 & 33.41 & 390 & 240 & 370 & - & - & - & - \\
\hline & -0.65 & $\mathrm{~A} / \mathrm{B}$ & 5.78 & 65.53 & 35.90 & 147 & 300 & 553 & & - & - & - \\
\hline & -1.5 & $\mathrm{Bi}_{1}$ & 6.41 & 55.79 & 12.28 & 327 & 280 & 393 & 116.00 & 90.00 & 59.05 & 2.20 \\
\hline & $-2.00+$ & $\mathrm{Bi}_{2}$ & 6.98 & 58.31 & 6.15 & 260 & 220 & 520 & - & - & - & - \\
\hline \multirow{4}{*}{ S3 (LAe-1) } & $0.00-0.29$ & $\mathrm{~A}$ & 5.67 & 52.73 & 16.9 & 400 & 80 & 520 & - & - & - & - \\
\hline & -0.37 & $\mathrm{~A} / \mathrm{B}$ & 5.26 & 50.66 & 16.12 & 300 & 80 & 620 & - & - & - & - \\
\hline & -0.66 & $\mathrm{Bw}_{1}$ & 4.93 & 60.53 & 12.07 & 260 & 120 & 620 & 101.50 & 85.00 & 40.50 & 2.00 \\
\hline & $-1.10+$ & $\mathrm{Bw}_{2}$ & 5.15 & 61.71 & 8.95 & 300 & 80 & 620 & - & - & - & - \\
\hline \multirow{3}{*}{ S4 (LVe) } & $0.00-0.36$ & $\mathrm{~A}$ & 6.41 & 78.43 & 38.71 & 520 & 120 & 360 & - & - & - & - \\
\hline & -0.58 & $\mathrm{~A} / \mathrm{B}$ & 5.60 & 65.09 & 11.29 & 360 & 120 & & - & - & - & - \\
\hline & $-1.30+$ & $\mathrm{Bw}_{1}$ & 5.69 & 63.25 & 10.51 & 400 & 50 & 550 & 25.50 & 170.00 & 44.07 & 0.30 \\
\hline \multirow{4}{*}{ S5 (LAdx-2) } & $0.00-0.13$ & $\mathrm{~A}$ & 5.64 & 40.19 & 19.70 & 700 & 60 & 240 & - & - & - & - \\
\hline & -0.24 & $\mathrm{~A} / \mathrm{B}$ & 4.23 & 52.54 & 19.08 & 560 & 120 & 320 & - & - & - & - \\
\hline & -0.38 & $\mathrm{~B} / \mathrm{A}$ & 5.45 & 45.61 & 14.56 & 460 & 100 & 440 & - & - & - & - \\
\hline & $-1.50+$ & $\mathrm{Bw}$ & 5.67 & 50.33 & 8.93 & 484 & 112 & 404 & 42.00 & 90.00 & 62.31 & 0.80 \\
\hline \multirow{4}{*}{ S6 (LVAe-1) } & $0.00-0.23$ & $\mathrm{~A}$ & 6.31 & 55.95 & 30.92 & 460 & 100 & 440 & - & - & - & - \\
\hline & -0.42 & $\mathrm{~A} / \mathrm{B}$ & 6.25 & 72.43 & 19.55 & 300 & 80 & 620 & - & - & - & - \\
\hline & -0.92 & $\mathrm{Bw}_{1}$ & 5.55 & 74.54 & 13.63 & 340 & 180 & 480 & 25.50 & 150.00 & 57.25 & 0.30 \\
\hline & $-1.56+$ & $\mathrm{Bw}_{2}$ & 4.95 & 54.8 & 8.95 & 260 & 120 & 620 & - & - & - & - \\
\hline \multirow{4}{*}{ S7 (LAe-2) } & $0.00-0.19$ & $\mathrm{~A}$ & 6.19 & 72.30 & 19.55 & 600 & 60 & 340 & - & - & - & - \\
\hline & -0.59 & $\mathrm{Bw}_{1}$ & 5.60 & 52.38 & 10.51 & 460 & 80 & 460 & 33.00 & 70.00 & 56.89 & 0.80 \\
\hline & -1.08 & $\mathrm{Bw}_{2}$ & 5.37 & 67.09 & 8.95 & 480 & 100 & 420 & - & - & - & - \\
\hline & $-1.50+$ & $\mathrm{Bw}_{3}$ & 4.85 & 37.16 & 8.18 & 380 & 160 & 460 & - & - & - & - \\
\hline
\end{tabular}

${ }^{(1)}$ S1 (LAdx-1), Latossolo Amarelo distrocoeso típico (Xanthic Hapludox); S2 (CXbe); Cambissolo Háplico Tb eutrófico latossólico (Eutrochrept); S3 (LAe-1), Latossolo Amarelo eutrófico típico (Xanthic Eutrudox); S4 (LVe), Latossolo Vermelho eutrófico chernossólico (Rhodic Eutrudox); S5 (LAdx-2), Latossolo Amarelo distrocoeso típico (Xanthic Hapludox); S6 (LVAe-1), Latossolo Vermelho-Amarelo eutrófico típico (Typic Eutrudox); S7 (LAe-2), Latossolo Amarelo eutrófico típico (Xanthic Eutrudox). SOM, soil organic matter. 
to Scheinost et al. (1998) and Bahia et al. (2014). The spectral curves for the diagnostic B horizons of each profile are shown in Figure 1.

After obtaining the spectra, the XYZ tristimulus values were determined, as defined by Commission International de L'Eclairage (Wyszecki \& Stiles, 1982). The Munsell values for hue, value, and chroma were calculated based on the XYZ coordinates using the software Munsell Conversion, version 6.4, according to Barrón et al. (2000) and Viscarra Rossel et al. (2010). Subsequently, the degree of redness (DOR) was calculated (Barrón et al., 2000), as: $\mathrm{DOR}=[(10-$ Hue $) \times$ Chroma $] /$ Value.

Soil color in the field was determined by visual observation, at the time of the morphological description of the profile, with the aid of the Munsell color system (Munsell, 1994). MS was determined in

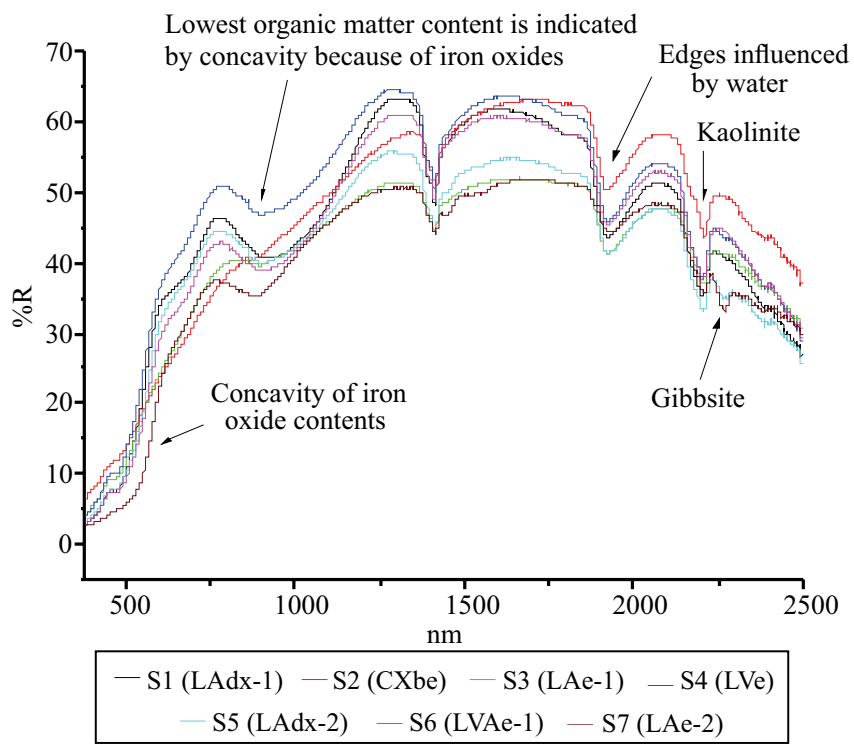

Figure 1. Spectral curves obtained by diffuse reflectance spectroscopy (DRS) for the following diagnostic B horizons of the evaluated soils: $\mathrm{Bw}_{1}$ of S1 (LAdx-1), Latossolo Amarelo distrocoeso típico (Xanthic Hapludox) ; $\mathrm{Bi}_{1}$ of S2 (CXbe), Cambissolo Háplico Tb eutrófico latossólico (Eutrochrept) $\mathrm{Bw}_{1}$ of $\mathrm{S} 3$ (LAe-1), Latossolo Amarelo eutrófico típico (Xanthic Eutrudox); $\mathrm{Bw}_{1}$ of S4 (LVe), Latossolo Vermelho eutrófico chernossólico (Rhodic Eutrudox); Bw of S5 (LAdx-2), Latossolo Amarelo distrocoeso típico (Xanthic Hapludox) ; $\mathrm{Bw}_{1}$ of S6 (LVAe-1), Latossolo VermelhoAmarelo eutrófico típico (Typic Eutrudox) ; and $\mathrm{Bw}_{1}$ of S7 (LAe-2), Latossolo Amarelo eutrófico típico (Xanthic Eutrudox). the ADFE, in a Bartington MS2 system, coupled to a MS2B dual-frequency sensor (Dearing, 1999); the MS values were at a low frequency of $0.47 \mathrm{kHz}$ (Dearing, 1994; Costa et al., 1999).

\section{Results and Discussion}

Spectral signature is an intrinsic property of each soil, as shown by the curves of the diagnostic B horizons (Figure 1). The S1, S4, and S6 soils presented the highest reflectance values in the range of the visible region $(250-780 \mathrm{~nm})$ and at the beginning of the NIR (780-2,500 $\mathrm{nm}$ ), besides marked concavities (Figure 1). According to Melo Filho et al. (2004), the greater the organic matter (OM) contents in the soil, the higher the concavity values of the spectral curve. However, this was not the case in the present study (Figure 1 and Table 1), nor in that of Demattê et al. (2003). These authors evaluated the effect of OM on spectral curves in soil samples in the state of São Paulo and found that the samples without OM showed higher reflectance values along the spectral curve. This opposite behavior was also observed for the S2, S3, and S5 soils, which showed higher OM contents (Table 1) and lower reflectance along the spectral curve (Figure 1).

$\mathrm{OM}$ affects various physical and chemical processes in soils, as well as the expression of their color, evidencing its close relation to their spectral signature (Dalmolin et al., 2005). For the studied soils, the greater proximity between the spectral curves, at the end of the NIR image (Figure 1), can be justified by the association of $\mathrm{OM}$ with minerals from the soil, which can also affect reflectance in certain bands. Clearly, in the band at $1,400 \mathrm{~nm}$, there are $\mathrm{OH}$ groups that are typical of the illite, smectite, and kaolinite minerals (Goetz et al., 2001). In the bands at 1,900 nm (Hunt \& Salisbury, 1970) and 1,920 nm (Bishop et al., 2008), there are water molecules linked to minerals and impurities; therefore, soil reflectance is characterized by various interferences and variations.

The less marked concavities observed in the band at $800-900 \mathrm{~nm}$ indicate the highest iron content in the samples (Dalmolin et al., 2005). The S3 soil showed the lowest total iron content of $40.50 \mathrm{~g} \mathrm{~kg}^{-1}$ and the highest reflectance, which decreased in the following soil order: S1, with $70.25 \mathrm{~g} \mathrm{~kg}^{-1}$ iron content; S6, with $57.25 \mathrm{~g} \mathrm{~kg}^{-1}$; S7, with $56.89 \mathrm{~g} \mathrm{~kg}^{-1}$; S5, with $62.31 \mathrm{~g} \mathrm{~kg}^{-1}$; 
S2 with $59.05 \mathrm{~g} \mathrm{~kg}^{-1}$, and S4, with total iron content of $44.07 \mathrm{~g} \mathrm{~kg}^{-1}$ and the lowest reflectance (Table 1). The differences among reflectance values and iron contents, greater between the S4 and S1 soils, can be explained by the effect of other attributes on the spectral curve.

Demattê et al. (2003) reported that the removal of OM allows the characteristic concavity of iron oxides to become more evident at $850 \mathrm{~nm}$, for soils with low iron content. In the present study, the lower OM content favored the higher reflectance of the S1 soil with higher iron content, whereas the higher OM content favored the lower reflectance of S4 with lower iron content, which should have encouraged greater reflectance. These results indicate that the spectral signature must be analyzed in association with other soil attributes in order to avoid erroneous interpretations. The crystallinity of iron oxides can also affect the spectral signature of each soil. When studying the effect of synthetic iron oxides on soil spectral signature, Cezar et al. (2013) observed that the greater specific surface area of more crystalline oxides causes a greater spread of photons by changing the final reflectance of the samples.

In the bands from 2,100 to 2,200 nm (Viscarra Rossel, 2011; Demattê et al., 2016), valleys that are characteristic of kaolinite $(\mathrm{Kt})$ were observed in the spectral curves, and, in the band at 2,265 $\mathrm{nm}$ (Demattê et al., 2000; Pizarro et al., 2001), valleys that are typical of gibbsite $(\mathrm{Gb})$. All the studied soils showed valleys in the spectral curves that are characteristic of Kt (Figure 1), but only some had valleys characteristic of $\mathrm{Gb}$. In the $\mathrm{S} 2$ and $\mathrm{S} 3$ soils, the more prominent valley was that of $\mathrm{Kt}$, and in $\mathrm{S} 4, \mathrm{~S} 5$ and $\mathrm{S} 7$, that of $\mathrm{Gb}$ (Figure 1).

The occurrence of $\mathrm{Gb}$ in the above mentioned soils is linked to their weathering rate (Pavelhão et al., 2016). Gb is easily formed in soils with good drainage conditions, first by rapid weathering and alteration of aluminosilicates, then by longer weathering that involves the complete desilicatization of $\mathrm{Kt}$ (Ker, 1994). Therefore, the structural grids of $\mathrm{Kt}$ and $\mathrm{Gb}$ have similar elements, such as $\mathrm{Al}, \mathrm{H}$, and $\mathrm{O}$ (with the exception of $\mathrm{Si}$ for $\mathrm{Kt}$ ), and may be associated in the spectral curves. Oliveira et al. (2013) studied the characterization of the spectral band in which Kt and $\mathrm{Gb}$ occur, and found great proximity between the valleys of the spectral curve, which makes it difficult to interpret one without the effect of the other.
Table 2 shows data from $\mathrm{Hm}$ and Gt obtained by the $\mathrm{XRD}$ and DRS techniques, as well as the correlation coefficients. High levels of correlation (close to 1) were obtained and can be used to estimate $\mathrm{Hm}$ and Gt for all soils, except $\mathrm{Hm}$ for $\mathrm{S} 1$, which showed a coefficient of 0.79 .

The results obtained in the present study indicate that DRS is an efficient technique for the indirect quantification of oxides, allowing a large number of samples to be evaluated. When studying Oxisols in the state of São Paulo, Brazil, Bahia et al. (2015) used DRS to accurately estimate the levels of Hm and Gt, also observing that the technique allows working with a higher sample density. Viscarra Rossel et al. (2010) validated DRS to estimate $\mathrm{Hm}$ and Gt for mapping soils in Australia. It should be noted that one of the major obstacles to the advancement in soil science in Brazil is detailed soil mapping, which is still scarce (Marques Jr. et al., 2014).

The MS values ranged from 0.01 to $0.46 \times 10^{-3} \mathrm{~m}^{3} \mathrm{~kg}^{-1}$ (Table 2). The $\mathrm{S} 4$ soil showed the highest MS values ( 0.28 to $0.46 \times 10^{-3} \mathrm{~m}^{3} \mathrm{~kg}^{-1}$ ) along the profile, and $\mathrm{S} 2$ showed MS of $0.15 \times 10^{-3} \mathrm{~m}^{3} \mathrm{~kg}^{-1}$ for the $\mathrm{Bi}_{2}$ horizon. The other soils showed low MS, ranging between 0.01 and $0.08 \times 10^{-3} \mathrm{~m}^{3} \mathrm{~kg}^{-1}$. These ranges are in agreement with those reported in the literature for soils rich in iron oxides, Hm, and Gt. Dearing (1994) highlighted that MS in both of these oxides is at detectable levels in the order of 0.3 to 1.7 and 0.3 to $1.2 \times 10^{-6} \mathrm{~m}^{3} \mathrm{~kg}^{-1}$, respectively.

Vasconcelos et al. (2013), when studying Oxisols and Inceptisols in the Cerrado of the state of Minas Gerais, Brazil, found higher MS values for Inceptisols and lower ones for Oxisols. According to these authors, MS has a negative correlation with Gt contents, which is attributed to the decrease of ferromagnetic minerals as this mineral increased, given the advancement in the weathering processes. This can explain the results found for most of the studied soils.

A lower MS is indicative of the presence of pedogenic magnetic minerals (Bartington Instruments, 2013), i.e., formed in the soil, indicating a greater degree of weathering. Silva et al. (2010), when studying samples of the B horizon of soils in the state of Paraná, Brazil, reported that higher MS values are related to soils derived from igneous rocks, while lower values are linked to metamorphic and sedimentary soils. In the present study, this can explain the lower MS values 
found in the evaluated soils, which are metamorphic, even though they have high quantities of iron oxides.

As for soil color, the hues observed in the field ranged from 2.5 to $10 \mathrm{YR}$ (Table 3). More grayish colors were observed in S2 and more reddish ones in S4. The other soils presented colors with yellowish to brownish shades. The more grayish colors in S2 are due to the lower iron oxide content in this soil, which also showed $\mathrm{Ki}$ of 2.20 and higher contents of $\mathrm{Fe}_{0}$, a less crystalline type of iron; therefore, this is the least weathered among the studied soils.

Most of the soil profiles in the present study showed variations in color and the presence of ferruginous concretions, which makes it more difficult to observe the color in the field and also generates different DRS results, since, for analyses in the device, the sample is macerated until the complete homogenization of the color (S2, S3, S5, S6, and S7). With the DRS

Table 2. Mineralogical characterization of the studied soils ${ }^{(1)}$.

\begin{tabular}{|c|c|c|c|c|c|c|c|c|c|c|}
\hline \multirow[t]{2}{*}{ Depth (m) } & \multirow[t]{2}{*}{ Horizon } & $\mathrm{Gt}_{\mathrm{XRD}}$ & $\mathrm{Gt}_{\mathrm{DRS}}$ & \multirow[t]{2}{*}{$\mathrm{r}$} & $\mathrm{Hm}_{\mathrm{XRD}}$ & $\mathrm{Hm}_{\mathrm{DRS}}$ & \multirow[t]{2}{*}{$\mathrm{r}$} & $\mathrm{Fe}_{\mathrm{d}}$ & $\mathrm{Fe}_{\mathrm{o}}$ & \multirow{2}{*}{$\begin{array}{c}\text { MS } \\
\left(10^{-3} \mathrm{~m}^{3} \mathrm{~kg}^{-1}\right)\end{array}$} \\
\hline & & \multicolumn{2}{|c|}{ 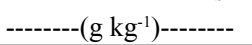 } & & \multicolumn{2}{|c|}{---------( $\left(\mathrm{g} \mathrm{kg}^{-1}\right)------$} & & \multicolumn{2}{|c|}{-------( $\left(\mathrm{g} \mathrm{kg}^{-1}\right)-------$} & \\
\hline & \multicolumn{10}{|c|}{ S1 (LAdx-1) } \\
\hline $0.00-0.28$ & A & 44.85 & 37.67 & 0.95 & 30.55 & 37.01 & 0.79 & 52.92 & 3.35 & 0.08 \\
\hline-0.63 & $\mathrm{~A} / \mathrm{B}$ & 59.96 & 47.42 & & 22.70 & 33.98 & & 58.15 & 4.57 & 0.06 \\
\hline-1.21 & $\mathrm{Bw}_{1}$ & 57.23 & 41.38 & & 26.91 & 41.16 & & 55.62 & 0.82 & 0.04 \\
\hline \multirow[t]{2}{*}{$-1.60+$} & $\mathrm{Bw}_{2}$ & 27.81 & 30.94 & & 46.47 & 43.65 & & 56.35 & 6.36 & 0.05 \\
\hline & \multicolumn{10}{|c|}{$\mathrm{S} 2(\mathrm{CXbe})$} \\
\hline $0.00-0.25$ & A & 1.25 & 1.31 & 0.95 & 2.12 & 2.07 & 0.91 & 19.32 & 17.05 & 0.02 \\
\hline-0.65 & $\mathrm{~A} / \mathrm{B}$ & 5.65 & 4.34 & & 6.73 & 7.91 & & 29.80 & 21.54 & 0.03 \\
\hline-1.50 & $\mathrm{Bi}_{1}$ & 10.90 & 16.74 & & 14.30 & 9.05 & & 24.20 & 7.34 & 0.01 \\
\hline \multirow[t]{2}{*}{$\underline{-2.00+}$} & $\mathrm{Bi}_{2}$ & 18.88 & 20.67 & & 16.47 & 14.86 & & 42.08 & 18.68 & 0.15 \\
\hline & \multicolumn{10}{|c|}{ S3 (LAe-1) } \\
\hline $0.00-0.29$ & A & 24.30 & 16.92 & 0.87 & 14.20 & 20.87 & 0.91 & 27.27 & 2.04 & 0.03 \\
\hline-0.37 & $\mathrm{~A} / \mathrm{B}$ & 13.50 & 15.94 & & 22.03 & 22.00 & & 26.01 & 2.12 & 0.03 \\
\hline-0.66 & $\mathrm{Bw}_{1}$ & 11.31 & 16.25 & & 24.77 & 20.33 & & 33.41 & 7.02 & 0.04 \\
\hline \multirow[t]{2}{*}{$-1.10+$} & $\mathrm{Bw}_{2}$ & 34.70 & 29.38 & & 42.11 & 28.80 & & 43.70 & 1.71 & 0.01 \\
\hline & \multicolumn{10}{|c|}{$\mathrm{S} 4(\mathrm{LVe})$} \\
\hline $0.00-0.36$ & $\mathrm{~A}$ & 25.18 & 23.15 & 0.99 & 7.38 & 9.20 & 0.99 & 29.08 & 8.08 & 0.28 \\
\hline-0.58 & $\mathrm{Bw}_{1}$ & 38.42 & 36.98 & & 18.18 & 19.48 & & 38.12 & 1.22 & 0.46 \\
\hline \multirow[t]{2}{*}{$\underline{-1.30+}$} & $\mathrm{Bw}_{2}$ & 31.18 & 30.28 & & 21.00 & 21.81 & & 36.66 & 2.36 & 0.45 \\
\hline & \multicolumn{10}{|c|}{ S5 (LAdx-2) } \\
\hline $0.00-0.13$ & A & 5.87 & 8.00 & 0.98 & 4.06 & 2.15 & 0.99 & 16.97 & 10.44 & 0.08 \\
\hline-0.24 & $\mathrm{~A} / \mathrm{B}$ & 18.46 & 25.68 & & 11.23 & 4.75 & & 21.67 & 2.20 & 0.06 \\
\hline-0.38 & $\mathrm{~B} / \mathrm{A}$ & 11.16 & 10.98 & & 11.63 & 11.78 & & 22.57 & 7.42 & 0.03 \\
\hline \multirow[t]{2}{*}{$\underline{-1.50+}$} & $\mathrm{Bw}$ & 52.04 & 49.45 & & 42.34 & 44.67 & & 72.78 & 10.44 & 0.01 \\
\hline & \multicolumn{10}{|c|}{ S6 (LVAe-1) } \\
\hline $0.00-0.23$ & $\mathrm{~A}$ & 10.80 & 19.42 & 0.90 & 30.33 & 22.58 & 0.99 & 29.80 & 1.79 & 0.04 \\
\hline-0.42 & $\mathrm{~A} / \mathrm{B}$ & 11.56 & 21.21 & & 33.82 & 25.14 & & 31.24 & 0.32 & 0.05 \\
\hline-0.92 & $\mathrm{Bw}_{1}$ & 5.56 & 15.32 & & 25.19 & 16.42 & & 37.92 & 16.81 & 0.05 \\
\hline \multirow[t]{2}{*}{$-1.56+$} & $\mathrm{Bw}_{2}$ & 15.02 & 20.63 & & 61.76 & 56.71 & & 57.61 & 4.98 & 0.01 \\
\hline & \multicolumn{10}{|c|}{ S7 (LAe-2) } \\
\hline $0.00-0.19$ & A & 3.86 & 2.47 & 0.99 & 4.44 & 5.69 & 0.99 & 8.30 & 2.77 & 0.01 \\
\hline-0.59 & $\mathrm{Bw}_{1}$ & 7.00 & 3.82 & & 7.43 & 10.29 & & 19.14 & 9.55 & 0.01 \\
\hline-1.08 & $\mathrm{Bw}_{2}$ & 46.40 & 33.63 & & 18.04 & 29.53 & & 46.77 & 4.98 & 0.01 \\
\hline$-1.50+$ & $\mathrm{Bw}_{3}$ & 60.46 & 46.74 & & 31.04 & 43.37 & & 62.66 & 2.94 & 0.01 \\
\hline
\end{tabular}

${ }^{(1)}$ S1 (LAdx-1), Latossolo Amarelo distrocoeso típico (Xanthic Hapludox); S2 (CXbe), Cambissolo Háplico Tb eutrófico latossólico (Eutrochrept); S3 (LAe-1), Latossolo Amarelo eutrófico típico (Xanthic Eutrudox); S4 (LVe), Latossolo Vermelho eutrófico chernossólico (Rhodic Eutrudox); S5 (LAdx-2), Latossolo Amarelo distrocoeso típico (Xanthic Hapludox); S6 (LVAe-1), Latossolo Vermelho-Amarelo eutrófico típico (Typic Eutrudox); S7 (LAe-2), Latossolo Amarelo eutrófico típico (Xanthic Eutrudox). Gt $t_{\mathrm{XRD}}$, goethite contents obtained by X-ray diffraction; Gt $\mathrm{Dt}_{\mathrm{DRS}}$, goethite contents obtained by diffuse reflectance spectroscopy; $\mathrm{Hm}_{\mathrm{XRD}}$, hematite contents obtained by X-ray diffraction; $\mathrm{Hm}_{\mathrm{DRS}}$, hematite contents obtained by diffuse reflectance spectroscopy; and r, coefficient of linear correlation between goethite and hematite contents obtained by the two techniques. 
technique, the colors showed hues between 3 and 10 YR. Compared with the colors obtained in the field, very different hues were observed in some soils (S2 and S4), while similar values were exhibited in others. However, in general, the values and chromas determined by the DRS technique were similar to those verified in the field, although the colors obtained differed, as shown by the illustration of colors (Table 3); S1 was the soil that presented the most similar colors.

Table 3. Soil ${ }^{(1)}$ color indexes obtained by diffuse reflectance spectroscopy (DRS) and field observation using the Munsell Chart.

\begin{tabular}{|c|c|c|c|c|c|c|c|c|c|}
\hline \multirow[t]{2}{*}{ Horizon } & \multicolumn{3}{|c|}{ DRS analysis } & \multirow[t]{2}{*}{ DOR } & \multicolumn{3}{|c|}{ Analysis by the Munsell chart } & \multirow[t]{2}{*}{ DRS color } & \multirow[t]{2}{*}{ Field color } \\
\hline & Hue & Value & Chroma & & Hue & Value & Chroma & & \\
\hline \multicolumn{10}{|c|}{ S1 (LAdx-1) } \\
\hline A & 7.81YR & 4.98 & 6.77 & 2.98 & $10 \mathrm{YR}$ & 5 & 8 & & \\
\hline $\mathrm{A} / \mathrm{B}$ & 7.59YR & 5.02 & 7.54 & 3.62 & $10 \mathrm{YR}$ & 5 & 8 & & \\
\hline $\mathrm{Bw}_{1}$ & $8.24 \mathrm{YR}$ & 5.38 & 7.37 & 2.41 & $10 \mathrm{YR}$ & 5 & 8 & & \\
\hline $\mathrm{Bw}_{2}$ & 8.43YR & 5.08 & 6.84 & 2.11 & $10 \mathrm{YR}$ & 5 & 8 & & \\
\hline \multicolumn{10}{|c|}{ S2 (CXbe) } \\
\hline A & 9.66YR & 4.32 & 3.46 & 0.27 & $2.5 \mathrm{Y}$ & 4 & 3 & & \\
\hline $\mathrm{A} / \mathrm{B}$ & 9.21YR & 4.48 & 3.54 & 0.62 & $2.5 \mathrm{Y}$ & 4 & 1 & & \\
\hline $\mathrm{Bi}_{1}$ & 9.34YR & 4.98 & 4.04 & 0.54 & $2.5 \mathrm{Y}$ & 5 & 3 & & \\
\hline $\mathrm{Bi}_{2}$ & $9.54 \mathrm{YR}$ & 4.95 & 4.32 & 0.40 & $2.5 \mathrm{Y}$ & 4 & 1 & & \\
\hline \multicolumn{10}{|c|}{ S3 (LAe-1) } \\
\hline A & $8.95 \mathrm{YR}$ & 5.03 & 5.41 & 1.13 & $7.5 \mathrm{YR}$ & 6 & 8 & & \\
\hline $\mathrm{A} / \mathrm{B}$ & $8.56 \mathrm{YR}$ & 5.35 & 6.24 & 1.68 & $7.5 \mathrm{YR}$ & 6 & 8 & & \\
\hline $\mathrm{Bw}_{1}$ & 8.19YR & 5.65 & 6.91 & 2.21 & $7.5 \mathrm{YR}$ & 6 & 8 & & \\
\hline $\mathrm{Bw}_{2}$ & 7.76YR & 5.29 & 6.90 & 2.92 & $7.5 \mathrm{YR}$ & 6 & 8 & & \\
\hline \multicolumn{10}{|c|}{ S4 (LVe) } \\
\hline A & $5.95 \mathrm{YR}$ & 3.77 & 5.55 & 5.96 & $2.5 \mathrm{YR}$ & 4 & 8 & & \\
\hline $\mathrm{A} / \mathrm{B}$ & $4.13 \mathrm{YR}$ & 4.21 & 7.35 & 10.25 & $2.5 \mathrm{YR}$ & 5 & 8 & & \\
\hline $\mathrm{Bw}_{1}$ & 3.82YR & 4.32 & 7.70 & 11.02 & $2.5 \mathrm{YR}$ & 5 & 8 & & \\
\hline \multicolumn{10}{|c|}{ S5 (LAdx-2) } \\
\hline A & 7.89YR & 4.5 & 5.07 & 2.38 & $10 \mathrm{YR}$ & 3 & 3 & & \\
\hline $\mathrm{A} / \mathrm{B}$ & $8.31 \mathrm{YR}$ & 4.19 & 4.80 & 1.94 & $10 \mathrm{YR}$ & 3 & 3 & & \\
\hline $\mathrm{B} / \mathrm{A}$ & 9.24YR & 4.93 & 4.95 & 0.76 & $10 \mathrm{YR}$ & 3 & 4 & & \\
\hline $\mathrm{Bw}$ & 9.03YR & 5.34 & 6.62 & 1.20 & $10 \mathrm{YR}$ & 6 & 8 & & \\
\hline \multicolumn{10}{|c|}{ S6 (LVAe-1) } \\
\hline A & $8.69 \mathrm{YR}$ & 4.63 & 5.30 & 1.50 & $7.5 \mathrm{YR}$ & 4 & 4 & & \\
\hline $\mathrm{A} / \mathrm{B}$ & $8.15 \mathrm{YR}$ & 5.18 & 6.01 & 2.15 & $7.5 \mathrm{YR}$ & 6 & 6 & & \\
\hline $\mathrm{Bw}_{1}$ & 7.03YR & 5.16 & 7.01 & 4.03 & $5 \mathrm{YR}$ & 5 & 6 & & \\
\hline $\mathrm{Bw}_{2}$ & 4.61YR & 4.83 & 6.66 & 7.43 & $5 \mathrm{YR}$ & 6 & 6 & & \\
\hline \multicolumn{10}{|c|}{ S7 (LAe-2) } \\
\hline A & $9.68 \mathrm{YR}$ & 4.77 & 4.52 & 0.30 & $10 \mathrm{YR}$ & 5 & 6 & & \\
\hline $\mathrm{Bw}_{1}$ & $9.27 \mathrm{YR}$ & 5.63 & 6.11 & 0.79 & $10 \mathrm{YR}$ & 5 & 8 & & \\
\hline $\mathrm{Bw}_{2}$ & 7.17YR & 5.00 & 6.73 & 3.81 & $10 \mathrm{YR}$ & 6 & 8 & & \\
\hline $\mathrm{Bw}_{3}$ & $8.16 \mathrm{YR}$ & 5.67 & 7.40 & 2.40 & $10 \mathrm{TR}$ & 6 & 6 & & \\
\hline
\end{tabular}

${ }^{(1)}$ S1 (LAdx-1), Latossolo Amarelo distrocoeso típico (Xanthic Hapludox); S2 (CXbe), Cambissolo Háplico Tb eutrófico latossólico (Eutrochrept); S3 (LAe-1), Latossolo Amarelo eutrófico típico (Xanthic Eutrudox); S4 (LVe), Latossolo Vermelho eutrófico chernossólico (Rhodic Eutrudox); S5 (LAdx2), Latossolo Amarelo distrocoeso típico (Xanthic Hapludox); S6 (LVAe-1), Latoswsolo Vermelho-Amarelo eutrófico típico (Typic Eutrudox); S7 (LAe2), Latossolo Amarelo eutrófico típico (Xanthic Eutrudox. ${ }^{(2)}$ DOR, degree of redness. 
Although determining colors in the field and in the laboratory involves different steps, the color obtained by DRS can be useful in various study conditions. Carmo et al. (2016), for example, assessed DRSestimated colors to distinguish areas regarding the yield and quality of coffee (Coffea arabica L.) bean, and Peluco et al. (2015) showed that the DOR, measured by DRS, can assist in mapping and identifying areas with different potential of phosphorus adsorption. It should be noted that $\mathrm{Hm}$ and Gt, two mineral pigment agents of soils (Lepsch, 2011), have different phosphorus adsorption capacities in the soil.

The DOR was higher in S4, reflecting the more reddish colors of this soil (Table 3), but still remained above 7 for the $\mathrm{Bw}_{2}$ horizon in $\mathrm{S} 6$ and above 3 for the same horizon in $\mathrm{S} 7$. Even though these soils did not show a reddish color, variation due to ferruginous concretions reached 10 and $20 \%$, respectively, on the surface of the horizons. Campos \& Demattê (2004) compared color ratings of 80 soil samples in the field through observations of five pedologists and a colorimeter. The authors explained that there are differences in the determination of hue that induce rating errors and also pointed out that, on average, researchers overestimate hue in Munsell determinations. This was observed in the present study: in most of the analyzed soils, hue was overestimated in the field, when compared with hue estimated by DRS. Aquino et al. (2016), when studying the colors of soils in the Brazilian Amazon, also found differences in the colors obtained by DRS and in the field for some of the Entisols and Ultisols evaluated.

The obtained results show that DRS is an alternative for minimizing errors, allowing the classification and study of soils in a correct manner, since color is an important attribute in the classification of soils into suborders and, in some orders, it can also directly indicate attributes inherent in soil genesis.

\section{Conclusions}

1. Diffuse reflectance spectroscopy (DRS) is a technique that can estimate hematite and goethite contents in soils in the Cerrado in the state of Goiás, Brazil.

2. DRS allows the accurate characterization of hue, value, and chroma, compared with the Munsell color system.

3. Spectral signature can differentiate between the diagnostic B horizons, according to the typical bands of organic matter, iron oxides, kaolinite, and gibbsite, indicating the stage of evolution of the studied soils.

\section{References}

AQUINO, R.E. de; MARQUES JR., J.; CAMPOS, M.C.C.; OLIVEIRA, I.A. de; BAHIA, A.S.R. de S.; SANTOS, L.A.C. dos. Characteristics of color and iron oxides of clay fraction in Archeological Dark Earth in Apuí region, southern Amazonas. Geoderma, v.262, p.35-44, 2016. DOI: 10.1016/j. geoderma.2015.07.010.

BAHIA, A.S.R. de S.; MARQUES JR, J.; PANOSSO, A.R.; CAMARGO, L.A.; SIQUEIRA, D.S.; LA SCALA JR., N. Iron oxides as proxies for characterizing anisotropy in soil $\mathrm{CO}_{2}$ emission in sugarcane areas under green harvest. Agriculture, Ecosystems and Environment, v.192, p.152-162, 2014. DOI: 10.1016/j.agee.2014.04.017.

BAHIA, A.S.R. de S.; MARQUES JR., J.; SIQUEIRA, D.S. Procedures using diffuse reflectance spectroscopy for estimating hematite and goethite in Oxisols of São Paulo, Brazil. Geoderma Regional, v.15, p.150-156, 2015. DOI: 10.1016/j. geodrs.2015.04.006

BARRÓN, V.; MELLO, J.W.V.; TORRENT, J. Caracterização de óxidos de ferro em solos por espectroscopia de reflectância difusa. In: NOVAIS, R.F.; ALVAREZ, V.H.; SCHAEFER, C.E.G.R. (Ed). Tópicos em ciência do solo. Viçosa: Sociedade Brasileira de Ciência do Solo, 2000. v.1, p.139-162.

BARRON, V.; TORRENT, J. Use of the Kubelka-Munk theory to study the influence of iron oxides on soil colour. Journal of Soil Science, v.37, p.499-510, 1986. DOI: 10.1111/j.1365-2389.1986. tb00382.x.

BARTINGTON INSTRUMENTS. Operation Manual for MS2 Magnetic Susceptibility System. Available at: <http:// www.bartington.com/Literaturepdf/Operation\%20Manuals/ om0408\%20MS2.pdf>. Accessed on: Jan. 242013.

BISHOP, J.L.; LANE, M.D.; DYAR, M.D.; BROWN, A.J. Reflectance and emission spectroscopy study of four groups of phyllosilicates: smectites, kaolinite-serpentines, chlorites and micas. Clay Minerals, v.43, p.35-54, 2008. DOI: 10.1180/ claymin.2008.043.1.03.

CAMARGO, L.A.; MARQUES JÚNIOR, J.; BARRÓN, V.; ALLEONI, L.R.F.; BARBOSA, R.S.; PEREIRA, G.T. Mapping of clay, iron oxide and adsorbed phosphate in Oxisols using diffuse reflectance spectroscopy. Geoderma, v.251-252, p.124-132, 2015. DOI: 10.1016/j.geoderma.2015.03.027.

CAMARGO, O.A. de; MONIZ, A.C.; JORGE, J.A.; VALADARES, J.M.A.S. Métodos de análise química, mineralógica e física de solos do Instituto Agronômico de Campinas. Campinas: IAC, 1986. 96 p. (IAC. Boletim técnico, 106).

CAMPOS, R.C.; DEMATTÊ, J.A.M. Cor do solo: uma abordagem da forma convencional de obtenção em oposição à automatização do método para fins de classificação de solos. Revista Brasileira de Ciência do Solo, v.28, p.853-863, 2004. DOI: 10.1590/S010006832004000500008 
CARMO, D.A.B. do; MARQUES JÚNIOR, J.; SIQUEIRA, D.S.; BAHIA, A.S.R. de S.; SANTOS, H.M.; POLLO, G.Z. Cor do solo na identificação de áreas com diferentes potenciais produtivos e qualidade de café. Pesquisa Agropecuária Brasileira, v.51, p.1261-1271, 2016. DOI: 10.1590/s0100-204x2016000900026.

CEZAR, E.; NANNI, M.R.; DEMATTÊ, J.A.M.; CHICATI, M.L.; OLIVEIRA, R.B. de. Estimativa de atributos do solo por meio de espectrorradiometria difusa. Revista Brasileira de Ciência do Solo, v.37, p.858-868, 2013. DOI: 10.1590/S010006832013000400004.

COSTA, A.C.S. da; BIGHAM, J.M.; RHOTON, F.E.; TRAINA, S.J. Quantification and characterization of maghemite in soils derived from volcanic rocks in southern Brazil. Clays and Clay Minerals, v.47, p.466-473, 1999. DOI: 10.1346/ CCMN.1999.0470408.

DALMOLIN, R.S.D.; GONÇALVES, C.N.; KLAMT, E.; DICK, D.P. Relação entre os constituintes do solo e seu comportamento espectral. Ciência Rural, v.35, p.481-489, 2005. DOI: 10.1590/ S0103-84782005000200042.

DEARING, J.A. Environmental magnetic susceptibility: using the Bartington MS2 system. England: British Library, 1994. 104p.

DEARING, J.A. Environmental magnetic susceptibility: using the Bartington MS2 system. $2^{\text {nd }}$ ed. rev. Kenilworth: Chi Publishing, 1999. 54p.

DEMATTÊ, J.A.M.; BELLINASO, H.; ARAÚJO, S.R.; RIZZO, R.; SOUZA, A.B. Spectral regionalization of tropical soils in the estimation of soil attributes. Revista Ciência Agronômica, v.47, p.589-598, 2016. DOI: 10.5935/1806-6690.20160071.

DEMATTÊ, J.A.M.; CAMPOS, R.C.; ALVES, M.C. Avaliação espectral de solos desenvolvidos em uma topossequência de diabásio e folhelho da região de Piracicaba, SP. Pesquisa Agropecuária Brasileira, v.35, p.2447-2460, 2000. DOI: 10.1590/ S0100-204X2000001200016.

DEMATTÊ, J.A.M.; EPIPHANO, J.C.N.; FORMAGGIO, A.R. Influência da matéria orgânica e de formas de ferro na reflectância de solos tropicais. Bragantia, v.62, p.451-464, 2003. DOI: 10.1590/ S0006-87052003000300012.

DICK, D.P. Caracterização de óxidos de ferro e adsorção de fósforo na fração argila de horizontes B Latossólicos. 1986. 196p. Dissertação (Mestrado) - Universidade Federal do Rio Grande do Sul, Porto Alegre.

FERNANDES, K.L.; RIBON, A.A.; MARQUES JUNIOR, J.; BAHIA, A.S.R. de S.; TAVARES FILHO, J. Characterization, classification and analysis of the main properties of the Southwestern Goias soil. Semina: Ciências Agrárias, v.37, p.1135-1154, 2016. DOI: 10.5433/1679-0359.2016v37n3p1135.

GOETZ, A.F.H.; CHABRILLAT, S.; LU, Z. Field reflectance spectrometry for detection of swelling clays at construction sites. Field Analytical Chemistry and Technology, v.5, p.143-155, 2001. DOI: 10.1002/fact.1015.

HUNT, G.R.; SALISBURY, J.W. Visible and near-infrared spectra of minerals and rocks: I. Silicate minerals. Modern Geology, v.1, p.283-300, 1970.
KÄMPF, N.; SCHWERTMANN, U. Goethite and hematite in a climosequence in Southern Brazil and their application in classification of kaolinitic soils. Geoderma, v.29, p.27-39, 1983. DOI: 10.1016/0016-7061(83)90028-9.

KER, J.C. Latossolos do Brasil: uma revisão. Geonomos, v.5, p.17-40, 1994.

KOSMAS, C.S.; CURI, N.; BRYANT, R.B.; FRANZMEIER, D.P. Characterization of iron oxide minerals by secondderivative visible spectroscopy. Soil Science Society of America Journal, v.48, p.401-405, 1984. DOI: 10.2136/ sssaj1984.03615995004800020036x.

KUBELKA, P.; MUNK, F. Ein beitrag zur optik der farbanstriche. Zeitschrift für Technische Physik, v.12, p.593-601, 1931.

LEPSCH, I.F. 19 lições de pedologia. São Paulo: Oficina de Textos, 2011.

MARQUES JR., J.; SIQUEIRA, D.S.; CAMARGO, L.A.; TEIXEIRA, D.D.B.; BARRÓN, V.; TORRENT, J. Magnetic susceptibility and diffuse reflectance spectroscopy to characterize the spatial variability of soil properties in a Brazilian Haplustalf. Geoderma, v.219-220, p.63-71, 2014. DOI: 10.1016/j. geoderma.2013.12.007.

MEHRA, O.P.; JACKSON, M.L. Iron oxide removed from soils and clays by dithionite citrate system buffered with sodium bicarbonate. Clays and Clay Minerals, v.7, p.3319-329, 1960.

MELO FILHO, J.F.; DEMATTÊ, J.A.M.; LIBARD, P.L.; PORTELA, J.C. Comportamento espectral de um Latossolo Amarelo coeso argissólico em função de seu uso e manejo. Magistra, v.16, p.105-112, 2004.

MULDER, V.L.; PLOTZE, M.; BRUIN, S. de; SCHAEPMAN, M.E.; MAVRIS, C.; KOKALY, R.F.; EGLI, M. Quantifying mineral abundances of complex mixtures by coupling spectral deconvolution of SWIR spectra $(2.1-2.4 \mu \mathrm{m})$ and regression tree analysis. Geoderma, v.207/208, p.279-290, 2013.

MUNSELL, R. Munsell soil color charts. rev. New Windson: Macbeth Division of Kollmorgen Instruments, 1994.

NORRISH, K.; TAYLOR, R.M. The isomorphous replacement of iron by aluminium in soil goethites. Journal of Soil Science, v.12, p.294-306, 1961. DOI: 10.1111/j.1365-2389.1961.tb00919.x.

OLIVEIRA, J.F.; BROSSARD, M.; VENDRAME, P.R.S.; MAYI III, S.; CORAZZA, E.J.; MARCHÃO, R.L.; GUIMARÃES, M. de F. Soil discrimination using diffuse reflectance Vis-NIR spectroscopy in a local toposequence. Comptes Rendus Geoscience, v.345, p.446-453, 2013. DOI: 10.1016/j. crte.2013.12.001.

PAVELHÃO, T.R.; PINESE, J.P.P.; SILVA, F.C.M. da; SACHS, L.G. Evolução pedológica de uma sequência de solos em Londrina - PR. Boletim de Geografia, v.34, p.23-35, 2016. DOI: 10.4025/ bolgeogr.v34i2.29349.

PELUCO, R.G.; MARQUES JÚNIOR, J.; SIQUEIRA, D.S.; PEREIRA, G.T.; BARBOSA, R.S.; TEIXEIRA, D. de B. Mapeamento do fósforo adsorvido por meio da cor e da suscetibilidade magnética do solo. Pesquisa Agropecuária Brasileira, v.50, p.259-266, 2015. DOI: 10.1590/S0100204X2015000300010.

Pesq. agropec. bras., Brasília, v.52, n.10, p.923-932, out. 2017 DOI: 10.1590/S0100-204X2017001000012 
PIZARRO, M.A.; EPIPHANIO, J.C.N.; GALVÃO, L.S. Caracterização mineralógica de solos tropicais por sensoriamento remoto hiperespectral. Pesquisa Agropecuária Brasileira, v.36, p.1277-1286, 2001. DOI: 10.1590/S0100-204X2001001000010.

RIBEIRO, J.F.; WALTER, B.M.T. As principais fitofisionomias do bioma Cerrado. In: SANO, S.M.; ALMEIDA, S.P. de; RIBEIRO, J.F. (Ed.). Cerrado: ecologia e flora. Brasília: Embrapa Informação Tecnológica, 2008. v.1, p.151-212.

SANTOS, H.G. dos; JACOMINE, P.K.T.; ANJOS, L.H.C. dos; OLIVEIRA, V.A. de; LUMBRERAS, J.F.; COELHO, M.R.; ALMEIDA, J.A. de; CUNHA, T.J.F.; OLIVEIRA, J.B. de. Sistema brasileiro de classificação de solos. 3.ed. rev. e ampl. Brasília: Embrapa, 2013. 353p.

SCHEINOST, A.C.; CHAVERNAS, A.; BARRÓN, V.; TORRENT, J. Use and limitations of second-derivative diffuse reflectance spectroscopy in the visible to near-infrared range to identify and quantify $\mathrm{Fe}$ oxide minerals in soils. Clays and Clay Minerals, v.46, p.528-536, 1998. DOI: 10.1346/ CCMN.1998.0460506.

SCHULZE, D.G.; SCHWERTMANN, U. The influence of aluminium on iron oxides: X. properties of Al-substituted goethites. Clay Minerals, v.19, p.521-539, 1984. DOI: 10.1180/ claymin.1984.019.4.02.

SILVA, A.R. da; SOUZA JUNIOR, I.G. de; COSTA, A.C.S. da. Suscetibilidade magnética do horizonte B de solos do Estado do Paraná. Revista Brasileira de Ciência do Solo, v.34, p.329-337, 2010. DOI: 10.1590/S0100-06832010000200006.

TORRENT, J.; BARRÓN, V. Laboratory measurement of soil color: theory and practice. In: BIGHAM, J.M.; CIOLKOSZ, E.J. (Ed.). Soil color. Madison: Soil Science Society America Journal, 1993. p.21-33. (SSSA. Special publication, 31).
VASCONCELOS, V.; MARTINS, E. de S.; CARVALHO JUNIOR, O.A. de; MARQUES JUNIOR, J.; SIQUEIRA, D.S.; COUTO JUNIOR, A.F.; GUIMARÃES, R.F.; GOMES, R.A.T.; REATTO, A. Modelo de evolução pedogeomorfológica da Serra da Canastra, MG. Revista Brasileira de Geomorfologia, v.14, p.197-212, 2013.

VISCARRA ROSSEL, R.A. Fine-resolution multiscale mapping of clay minerals in Australian soils measured with near infrared spectra. Journal of Geophysical Research: Earth Surface, v.116, 2011. DOI: 10.1029/2011JF001977.

VISCARRA ROSSEL, R.A.; BEHRENS, T.; BEM-DOR, E.; BROWN, D.J.; DEMATTÊ, J.A.M.; SHEPHERD, K.D.; SHI, Z.; STENBERG, B.; STEVENS, A.; ADAMCHUK, V.; AÏCHI, H.; BARTHÉS, B.G.; BARTHOLOMEUS, H.M.; BAYER, A.D.; BERNOUX, M.; BÖTTCHER, K.; BRODSKÝ, L.; DU, C.W.; CHAPPELL, A.; FOUAD, Y.; GENOT, V.; GOMEZ, C.; GRUNWALD, S.; GUBLER, A.; GUERRERO, C.; HEDLEY, C.B.; KNADEL, M.; MORRÁS, H.J.M.; NOCITA, M.; RAMMIREZ-LOPEZ, L.; ROUDIER, P.; RUFASTO CAMPOS, E.M.; SANBORN, P.; SELLITTO, V.M.; SUDDUTH, K.A.; RAWLINS, B.G.; WALTER, C.; WINOWIECKI, L.A.; HONG, S.Y.; JI, W. A global spectral library to characterize the world's soil. Earth-Science Reviews, v.155, p.198-230, 2016. DOI: 10.1016/j.earscirev.2016.01.012.

VISCARRA ROSSEL, R.A.; BUI, E.N.; CARITAT, P.; MCKENZIE, N.J. Mapping iron oxides and the color of Australian soil using visible-near-infrared reflectance spectra. Journal of Geophysical Research: Earth Surface, v.115, F.04031, 2010. DOI: 10.1029/2009JF001645.

WYSZECKI, G.; STILES, W.S. Color science: concepts and methods, quantitative data and formulae. $2^{\text {nd }}$ ed. New York: J. Wiley \& Sons, 1982. 976p.

Received on August 25, 2016 and accepted on February 20, 2017 